\title{
Cumulative material flows provide indicators to quantify the ecological debt
}

\author{
Andreas Mayer ${ }^{1}$ \\ Willi Haas \\ Alpen-Adria University, Austria
}

\begin{abstract}
There is ample evidence that an unabated growth in material consumption is likely to pass the earth system's source and sink capacities. In the face of limited resources, distributional questions increasingly gain importance. Material flow accounting is a methodological tool to trace biophysical patterns of disproportionate resource consumption across countries and the debt towards the environment, other parts of the world, and towards future generations through the excessive consumption of natural resources. At the core of this article, we address different developments of material use for individual countries and world regions from 1950 to 2010. During this phase, fossil fuel-based industrialization triggered an unprecedented growth in material consumption, mainly in the wealthy world regions of Europe, Australia, North America, and partly in the countries of the former Soviet Union, while low resource consumption persists in other regions. We thus calculated cumulative resource use from 1950 to 2010 to show the extent of this wealth built up upon countries' own resources, or through imports from other countries or world regions. We use the degree of net-import dependency of individual countries as a proxy for the ecological debt, and relate it to the domestic resource extraction in a country. Our observations show that there was a highly uneven distribution of resource extraction and use in the 60 years analyzed, which has important implications for future global resource policies.
\end{abstract}

Keywords: Ecological debt, material flow accounting, international trade, global resource use

\section{Résumé}

Il est amplement prouvé qu'une croissance sans relâche dans la consommation matérielle est susceptible de passer les capacités du système de terre. Face à des ressources limitées, les questions de redistribution acquièrent de plus en plus d'importance. La comptabilisation des flux de matières est un outil méthodologique pour tracer des modèles biophysiques de la consommation des ressources disproportionnées entre les pays, et la dette due à l'environnement, d'autres parties du monde, et envers les générations futures, par la consommation excessive des ressources naturelles. Au cœur de cet article, nous examinons l'évolution de l'utilisation des matériaux par les différents pays et régions du monde à partir de 1950 jusqu'à 2010. Au cours de cette phase, l'industrialisation à base de combustibles fossiles a déclenché une croissance sans précédent de la consommation matérielle, principalement dans les régions riches du monde - Europe, Australie, Amérique du Nord, et dans certains des pays de l'ex-Union soviétique. Une faible consommation de ressources a persisté dans d'autres régions. Nous avons donc calculé l'utilisation des ressources cumulative entre 1950 et 2010 pour montrer l'étendue de cette richesse qui a été construit sur les ressources propres des pays, ou par les importations en provenance d'autres pays ou régions du monde. Nous utilisons le degré de dépendance nette des importations des pays en tant que proxy pour la dette écologique, et se rapportent à l'extraction des ressources nationales dans un pays. Nos observations montrent qu'il y avait une répartition

\footnotetext{
${ }^{1}$ Andreas Mayer and Dr. Willi Haas, Institute of Social Ecology, Alpen Adria University, Klagenfurt, Austria. Email: andreas.mayer"at"aau.at, willi.haas"at"aau.at. The authors gratefully acknowledge funding from the European Commission for the project EJOLT (EU-FP7 project under grant agreement no 266642) and the Austrian Science Fund (FWF; Project MISO P27590). This is the second article in Alf Hornborg and Joan Martinez-Alier (eds.) 2016. "Ecologically unequal exchange and ecological debt", Special Section of the Journal of Political Ecology 23:328-491.
} 
très inégale de l'extraction et l'utilisation des ressources de plus de 60 ans, ce qui a des implications importantes pour les politiques de gestion des ressources mondiales à l'avenir.

Mots-clés: la dette écologique, la comptabilité des flux de matières, le commerce international, l'utilisation des ressources mondiales

\section{Resumen}

Existen amplias pruebas de que el crecimiento continuado del consumo material probablemente sobrepasa las capacidades de suministro y de sumidero de los sistemas de la Tierra. Si los recursos son limitados, las cuestiones distributivas ganan importancia. La contabilidad de flujos de materiales es una herramienta metodológica capaz de seguir las pautas biofísicas del consumo desproporcionado de recursos en diversos países y determinar la deuda ecológica por el consumo excesivo de recursos naturales hacia el ambiente natural, hacia otras partes del mundo y hacia las generaciones futuras. En este artículo consideramos distintos desarrollos del uso de materiales en distintos países y regiones mundiales desde 1950 hasta 2010. En este periodo, la industrialización basada en los combustibles fósiles llevó a un crecimiento sin precedentes en el consumo material, sobre todo en regiones ricas como Europa, Australia, Norte América y en parte en países de la antigua Unión Soviética, mientras en otras regiones persiste un bajo consumo de recursos. Hemos calculado el uso acumulado de recursos entre 1950 y 2010 para mostrar hasta qué punto esa riqueza se debe a los recursos propios de cada país o a las importaciones de otros países o regiones mundiales. Podemos usar el grado de dependencia de importaciones netas como una medida de la deuda ecológica, y relacionarlo con la extracción interna de recursos en el país. Concluimos que la extracción y el uso de recursos fueron muy desiguales durante esos 60 años, lo que tiene implicaciones importantes para futuras políticas de uso de recursos.

Palabras clave: deuda ecológica, contabilidad de flujos de materiales, comercio internacional, uso global de recursos

\section{Introduction}

Many countries are still engaged in the global socio-metabolic transition from an agrarian to an industrialized mode of production and the corresponding material use trajectory (Krausmann et al. 2008; Schaffartzik et al. 2014). However, individual countries or population groups are at different stages of this transition, so the speed of the transition varies across countries and the emerging metabolic profiles differ widely (Hashimoto et al. 2012). Social metabolism refers to the dependency of socio-economic systems on a continuous throughput of materials and energy for their reproduction and maintenance, whereas the scale and structure of this throughput is strongly coupled to social, economic, political, and cultural factors. It is considered functionally equivalent to biological metabolism, the organism's dependency on material and energy flows, only coupled to social organization and therefore referred to as "social metabolism" (FischerKowalski and Weisz 1999; Schaffartzik and Mayer 2015). Global social metabolism grew significantly during the last century, from around 8 billion tons (Gt) in 1900 to 60 Gt in 2005, a nearly 8-fold increase. Although population growth is one factor behind these figures, per capita material consumption also increased significantly from 4.6 to 10.3 t/cap/yr (Krausmann et al. 2009). Researchers have discussed the linkages between resource use and human development at various scales, and their results indicate that certain levels of resource use are necessary to satisfy human needs (Steinberger et al. 2012; Steinberger and Roberts 2010), while this link is weakened at higher levels of material wealth. However, the link between material use and economic growth is linear and does not show a break of this kind (Dietz et al. 2007; Steinberger et al. 2010; UNEP 2011). The industrialized countries and many developing and emerging countries base their development models on economic growth and it has been recognized that the consequences of growing social metabolism jeopardize the stability of socio-ecological systems at the global level (Rockström et al. 2009; Victor 2010). The disproportionately high levels of resource consumption in some parts of the world have created a debt towards the environment, towards other parts of the world, and also towards future generations through the excessive consumption of non-renewable resources (Azar and Holmberg 1995; Debt Treaty 1992; Goeminne et al. 2009; Goeminne and Paredis 2009; Paredis et al. 2008; Robleto and Marcelo 1992). 
The expansion of global social metabolism to new regions of extraction and consumption and the use of materials and energy form the basis for economic growth, yet they are also associated with a wide range of negative impacts. Social metabolism has expanded its frontiers of extraction in the global South, and recent debates on neo-extractivism in Latin America or land grabbing in Sub-Saharan Africa and Latin America are expressions of concern about this expansion. While during the phase of high world market prices at the beginning of the $21^{\text {st }}$ century, the expansion of industrial resource extraction was beneficial for the financial households of many states in the global South, there was also mounting evidence of negative impacts. These include land use change, deforestation, biodiversity loss, increasing waste and emissions, water scarcity, and socio-environmental conflicts (Borras Jr and Franco 2012; Bunker and Ciccantell 2005; Foley et al. 2005; GRAIN et al. 2014; Gudynas 2010; Kastner et al. 2012; Martinez-Alier 2002; Temper and Martinez-Alier 2012). These impacts range from the local, up to the community and lastly to the global level. The environmental risk transition framework (Smith and Ezzati 2005; Wilkinson et al. 2007) indicates that environmental risks shift with increasing wealth from an immediate and local level towards a delayed and global scale. The hypothesis claims that there is an interdependence between the scale level of environmental risks and the level of economic wealth. While household-related problems like indoor pollution and sanitation diminish with growing wealth, the severity of community-wide burdens (e.g. urban pollution) display a hump-shaped curve, and environmental burdens on the global scale, such as global warming, are strongly coupled to economic growth and do not diminish with growing wealth (Canadell et al. 2007).

The concept of ecological (or environmental) debt appeared as a response to the economic debt that was putting pressure on the global South, and which is considered a mechanism of the North to exploit Southern peoples and the environment. The main argument was that the South is not simply a debtor to the North, but instead the North has generated an ecological debt towards the South through the long-term exploitation of its natural resources and sinks. This grassroots concept was used and further developed by a number of CSOs and activists, and increasingly found its way into science (Goeminne and Paredis 2010; Paredis et al. 2008). Warlenius et al. (2015: 25) build upon the extensive work that Paredis et al. (2008) brought together and conclude, "...an ecological debt can be said to have accrued when one country causes ecological damage in another country or to the global commons."

This definition emphasizes two dimensions of the ecological debt, which were also addressed in a study by Azar and Holmberg (1995), who quantified the ecological debt generated by Belgium. The first dimension describes the debt created within a country's own domestic territory. Here, two questions arise. The first question is whether every alteration of the environment is to be viewed as an environmental problem. The definition of an environmental problem is socially constructed, and Paredis et al. (2008) distinguish between three interferences: pollution, depletion, and degradation. The latter two interferences are those with which we are concerned in this study (and further referred to as environmental pressures). The second question is whether a country can owe an ecological debt to itself, which links to inter-generational aspects of the ecological debt. When current economic activity infringes upon the opportunities for future generations to sustain their basic needs, as defined in the Brundtland report (Brundtland et al. 1987), the current population has created an ecological debt towards future generations.

The second dimension of the ecological debt is related to international trade. Researchers argue that unjust regulatory conditions between Northern and Southern countries in the exchange of resources are the main reason why the global North is indebted to the South in ecological terms (Warlenius et al. 2015). Here we quantify the net trade of physical resources at the country level over the period of 1950-2010. For netimporting countries who are the debtors, the import of physical resources is understood as a displacement of environmental pressures from their domestic environment. For the net-exporting nations who are the creditors, export production has implied the pollution, depletion, and degradation of their resource base.

The concept of ecological debt is used to describe cumulative historical environmental injustices and there are several approaches used to quantify it (Warlenius et al. 2015). Environmental injustice, like ecological debt, is a rather vague concept. Joan Martinez-Alier (Paredis et al. 2008; Warlenius et al. 2015) underlines two aspects: firstly, unequal exchange, which is defined as "the fact of exporting products from poor regions and countries, at prices which do not take into account the local externalities caused by these 
exports or the exhaustion of natural resources, in exchange for goods and services from richer regions." and secondly, "... the tendency of wealthy countries to disproportionately utilize environmental space without paying for it" (both citations from Warlenius et al. 2015: 25). Both aspects are often measured in monetary value, in order to compare the debt that the North has created towards the South to the financial debt burden from which most Southern countries are suffering. The first studies were published in the 1990s and early 2000s - a detailed listing of such studies can be found in Paredis et al. (2008). Recently, several studies have focused on the ecological debt in terms of annual or accumulated carbon emissions. The most recent and comprehensive assessments of ecological debt were undertaken by Srinivasan et al. (2008), who calculated the costs of different human activities from 1961 to 2000 in terms of the environmental impact on human populations.

Most of the studies mentioned above quantify the ecological debt in monetary terms, but biophysical flows have to be calculated before they can be monetarized. In the present study, we address the ecological debt from a biophysical perspective only, considering the size and composition of the social metabolism as a proxy for environmental pressures from human activities (Fischer-Kowalski et al. 2011; Haberl et al. 2009; Seppaelae et al. 2009). We recognize that it is important to quantify the ecological debt in monetary terms, but agree with the argument of John Dillon (2001) that the "...ecological debt must never be reduced to demands for monetary compensation alone." Duncan McLaren (2003) also argues that the monetarization of the ecological debt exhibits a variety of shortcomings, including the fact that prices can never fully reflect all the externalities related to resource extraction and use and that the marketization of environmental services is neither possible nor desirable. Paredis et al. (2008: 71) conclude "...monetary valuation is not a necessary step for all aspects of ecological debt." Finally, while civil society organizations and grassroots movements admit that monetarization can be useful for communication, they also insist on using the numerous nonmonetary forms of valuation so as not to be restricted by the too narrow view of monetarization (MartinezAlier 2002).

In a world of finite, unevenly distributed resources, with resource shortages and sink limitations becoming more evident in the future (Turner 2008), questions of distribution, attribution, and liability will acquire more weight. The assessment of historical resource flows follows the principle outlined for carbon emissions in the 'Brazilian proposal', quantifying how unevenly individual countries' shares in the global metabolic pattern are distributed (Elzen et al. 2005 1999; La Rovere et al. 2002; Trudinger and Enting 2005). While the consumption of carbon-rich matter is a major driver for climate change, minerals and metals are linked to mining and waste conflicts (Alter 1997; Ayres 1997; Bebbington et al. 2008; Bebbington and Williams 2008; Demaria 2010; Özkaynak and Rodríguez-Labajos 2012). Lately, a growing body of scientific literature has dealt with urban mines, i.e. metals integrated into stocks such as buildings, infrastructure, and durable products. Considerable amounts of metal ores and products are traded on world markets, yet the countries where the metals were first extracted are in many cases not the countries where they are now stocked. This raises important questions regarding control over strategic materials that are important for future industrial development (Graedel 2011; Graedel and Cao 2010). Apart from the exhaustion and redistribution of non-renewable resources, renewable resources may be negatively impacted through degradation or pollution. If agriculture and forestry, the main sources of biomass consumed by humans, are not practiced sustainably - which is increasingly the case in industrialized production systems - agriculture becomes a non-renewable practice. Deforestation, degradation of agricultural lands, nutrient leaching, fertilizers and pesticide use are the main problems of unsustainable agricultural practices (Burchardt and Dietz 2014; Dirzo and Raven 2003; Vitousek et al. 1997).

Based on the arguments outlined above, we define the ecological debt as two-fold: Firstly, nations create an ecological debt when they have high resource extraction in relation to their domestic environment. Secondly, countries that import more resources than they export are responsible for parts of the trade partner's ecological debt, and they avoid environmental pressure on their domestic environments. These aspects provide a framework for a quantitative investigation of intra- and inter-generational equity (Brundtland et al. 1987) and relate to the aspects defined by Martinez-Alier (2002) and Paredis et al. (2008), 
recently reviewed by Warlenius et al. (2015). Equity, as understood here, remains merely a theoretical target, but is useful to calculate which countries have made disproportionate use of global resources.

\section{Economy-wide material flow accounting as a place-based investigation of the ecological debt}

We calculate indicators for cumulative material extraction and use from 1950 to 2010 that are based on recently published data on annual material flows (Schaffartzik et al. 2014). We present these indicators on a country-by-country basis, but we also group countries into regions whenever appropriate.

Material flow accounting, the methodological tool for quantifying the extent and structure of social metabolism, accounts for in- and outflows of physical matter into socioeconomic systems, except water and air, thus quantifying the economy-wide material use in physical units (EUROSTAT 2012; Fischer-Kowalski et al. 2011). We base the analysis on a MFA dataset presented by Schaffartzik et al. (2014), which was assembled according to the principles of economy-wide material flow accounting (EW-MFA). Annual flows of 65 material types were gathered and aggregated into six main material groups: biomass, fossil energy carriers, metal ores, industrial minerals, construction minerals, and other traded products which cannot be allocated to one of the main raw material groups. Data on domestic extraction (DE), imports, and exports was gathered for the years 1950, 1960 (1962), 1970, 1980, 1990, 2000, 2005, and 2010 for 177 countries, mostly based on international statistical sources. The indicators used here are all calculated based on these three flows. Further details on data gathering, aggregation procedure, and necessary methodological adaptations from the procedures in EUROSTAT (2012) for a time series going back to 1950 are described in Krausmann et al. (2009) and Schaffartzik et al. (2014).

We measure here direct flows and do not quantify hidden flows that are associated with material extraction and trade. Trade flows are measured when they cross the border of a socioeconomic system, and thus provide information on the global redistribution of physical matter as direct inputs to these socioeconomic systems (i.e. a country or a region). This methodology is referred to as place-based assessment, while consumption-based assessments include the hidden flows associated with trade (Muñoz et al. 2009; Schaffartzik et al. 2015; Wiedmann et al. 2015). An example that illustrates the difference between place-based and consumption-based assessments is traded metal ores and products, and the waste rock associated with their extraction and refinement. Place-based assessments allocate the waste rock to the country where the extraction took place. Thus, waste rock is classified as material use within the exporting country. Consumption-based assessments allocate waste rock to the country that imports the metal. The argument here is that when all material flows associated with the production of a consumer good are allocated to the respective good, the total material requirements associated with final consumption are reflected more adequately.

Material flow accounting records the mass of physical flows that enter and leave socioeconomic systems per year. They thus allow a set of (a) comparisons of different socioeconomic systems within one year, i.e. cross-sectional analysis between countries, and (b) longitudinal analysis of one country or a few countries. While both approaches deliver insights on development, size, structure, etc. of the social metabolism of the socioeconomic systems analyzed, we aim here at a combination of the two approaches. Cumulative material flows quantify all materials that were extracted from the domestic environment of a socioeconomic system, as well as all physical trade flows over time. The term 'cumulative material flows' is close to recent approaches that quantify the physical stocks of a system, and is partly based on the same data sources (Pauliuk et al. 2013; Wiedenhofer et al. 2015). Societal in-use stocks are the currently 'remaining' physical materials that are in societal use, such as infrastructure, buildings, or large machines. Cumulative flows, however, also include materials that are not used to build up such stocks. These flows of biomass and fossil fuels do not end up as societal in-use stocks, yet a considerable share is used to provide energy that is required to build these stocks up. 
In order to calculate cumulative flows, we have cumulatively added annual data from 1950 to 2010 to derive the total values for DE, imports, and exports. Wherever we refer to cumulative flows, we add the acronym $_{1950-2010}$ to the respective indicator.

$\mathrm{DE}_{1950-2010}=\mathrm{DE}_{1950}+\mathrm{DE}_{1951+\ldots+} \mathrm{DE}_{2010}$

$\mathrm{DE}_{1950-2010}$ is the sum of the cumulative domestic extraction in country A for the period 19502010 .

As noted above, the primary data was compiled for ten-year intervals (except 2005), thus we had to fill the intermediate data gaps. We have assumed linear development between the years for which we have data. We are aware that this method does not reflect real-world developments, as many of the published MFA studies show. However, as a first attempt to quantify the overall material use within this time span on a global level, we consider our data a useful base to start with and from which to improve the validity of these indicators. Linear interpolation assumes constant growth for every year that is missing between two points in time. We have thus added the average annual growth for every missing year in our database, e.g. if DE was $10 \mathrm{t}$ in 1980, and $110 \mathrm{t}$ in 1990, we have calculated that DE was 20t in 1981, 30t in 1982 and so on, based on an average annual growth of $10 \mathrm{t}$.

We use the following indicators:

$$
\begin{aligned}
& \mathrm{DMI}_{1950-2010}=\mathrm{DE}_{1950-2010}+\mathrm{Im}_{1950-2010} \\
& \mathrm{DMC}_{1950-2010}=\mathrm{DE}_{1950-2010}+\mathrm{Im}_{1950-2010}-\mathrm{Ex}_{1950-2010} \\
& \mathrm{PTB}_{1950-2010}=\mathrm{Im}_{1950-2010}-\mathrm{Ex}_{1950-2010}
\end{aligned}
$$

The indicators $\operatorname{Im}_{1950-2010}, \mathrm{Ex}_{1950-2010}$, and $\mathrm{PTB}_{1950-2010}$ compile all direct trade flows that cross national borders. When we analyze country groupings, however, they include not only the trade flows into or out from a certain country grouping, but also the trade flows between the countries that make up that grouping.

\section{Material extraction and the debt to the environment}

The uneven distribution of resource use at the global level is reflected in high material standards of living in the industrialized parts of the world, while poverty, food insecurity, and low living standards persist in other parts. We firstly take a look into countries' historic resource extraction rates. Countries with high material extraction rates per area have generated a higher debt towards their domestic environment through their disproportionate extraction of renewable and non-renewable matter than have countries with low rates. Furthermore, the depletion of non-renewable materials and the degradation of soils to produce biomass may infringe on the resource needs of future generations. In order to relate the material extraction in a country to the materials available, we have divided $\mathrm{DE}_{1950-2010}$ by the country area in the year 2010. $\mathrm{DE}_{1950-2010} / \mathrm{area}$ is thus an indicator of the cumulative environmental pressure that was exerted on the domestic environment in a country. Figure 1 shows a global map of the cumulative extraction per area ( $\mathrm{DE}_{1950-2010} /$ area in tons/ha) for 148 countries and 2 country aggregates (the former USSR and former Yugoslavia SFR).

Western European countries, in general densely populated and highly industrialized, are the countries that have exerted the highest pressure on their domestic environments. There are numerous examples of local and communal environmental problems during these 60 years, many of which were resolved through the common efforts of civil society and governments, putting regulations in place and stimulating technological change. Despite the hypotheses of the environmental risk transition framework, that increasing wealth shifts environmental risks from the local to the global level, there is mounting evidence that the local and community burdens were shifted from the industrialized countries to the new frontiers of material extraction in the global South (Muradian and Martinez-Alier 2001; Sassen 2013; Schaffartzik et al. 2016). Another region facing high pressure on its environment is East Asia, particularly China, Japan, South Korea, and India. Recent economic growth rates in China and India increased environmental pressures, and as these four 
countries also have high population densities, the effects often impact people more directly than in low populated countries. The highest $\mathrm{DE}_{1950-2010}$ per area are to be found in relatively small countries that extract underground resources such as oil and gas (Kuwait, Bahrain, and Qatar). Countries that were important resource providers on world markets, such as Brazil, Australia, Russia, Indonesia, the US and Canada, exerted comparably lower pressure on their domestic environments. This is partly because they are relatively large, while there is extensive proof that the extraction of renewable and non-renewable materials often impact on local populations and the environment (EJOLT 2014).

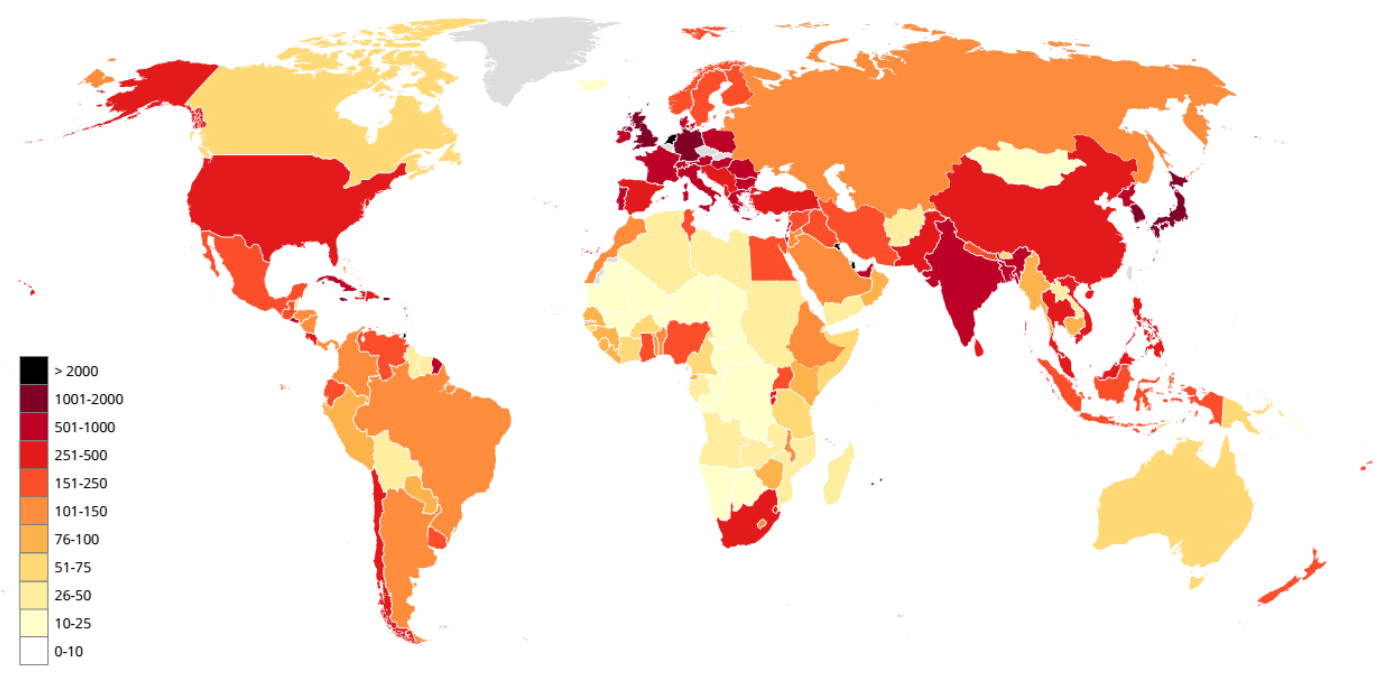

Figure 1: Cumulative domestic extraction ( $\left.\mathrm{DE}_{1950-2010}\right)$ per area in $[\mathrm{t} / \mathrm{ha}]$. Data from Schaffartzik et al. (2014).

\section{Trade and the debt towards other nations}

In most of the countries included in this analysis, the majority of used materials were extracted from the domestic environment; with traded materials playing a minor role in comparison (notable exceptions are the Netherlands, Singapore, or some small island states). However, this pattern is changing over time, with trade gaining more and more importance. Trade plays a particularly important role for point resources, which are extracted from natural deposits where they are stored in relatively concentrated form such as fossil energy carriers and metal ores. In contrast, biomass used to be a resource that was hardly traded at all, but that is now becoming increasingly important (Kastner et al. 2014). The overall trade pattern of a country can either be positive ( PTB $_{1950-2010}$ ), when imports exceed exports, negative, when more materials were exported than imported, or balanced. The latter can be a result either of an absence of trade or of a high, bilateral integration with the world market. Data shows that only developing and the least developed countries come close to balanced PTB $1950-2010$, mostly because there is little overall trade.

Figure 2 shows a global map for the cumulative physical trade balance divided by the same countries land area for 148 countries and 2 country aggregates. If a country was an overall net importer, PTB P50- $_{1950}$ 2010/area indicates the amount of pressure on the domestic environment that has been displaced through the import of materials from abroad and thus that the country has an ecological debt to other countries. An overall net-exporting pattern indicates that a country has carried parts of the environmental burden for other countries' resource use and is thus a creditor in ecological terms. The indicator $\mathrm{PTB}_{1950-2010}$ /area quantifies the displaced pressure through resource extraction, as the import of materials decreases domestic environmental pressure, but these imports also increase the domestic waste output of the importing nation (Weisz et al. 
2006). Moreover, countries also import raw-materials and products for the simple reason that they do not own the required resources, although there may also be numerous political and economic reasons involved. The map shows that resource extraction and consumption were not balanced over the last 60 years, as the countries marked in greener colors displaced pressure on their domestic environments through imports, while the countries marked in redder colors have borne the environmental costs of other countries through the extraction and export of more materials than they have imported. The countries that had the lowest pressures had little trade overall ( -5 - 5 t/ha), while countries where local pressure was dispersed over very large territories had up to -20 t/ha (Australia, USSR, Brazil, Argentina, and Canada). These countries are well endowed with renewable and non-renewable resources and had low population densities during the whole period considered.

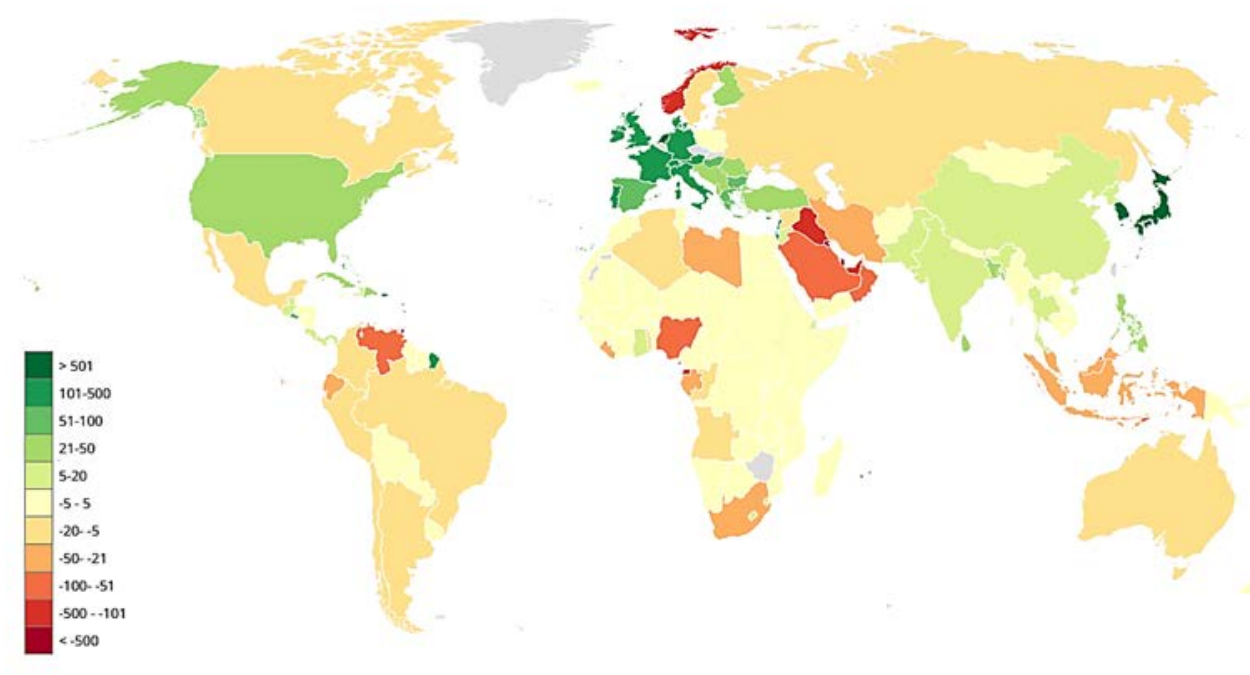

Figure 2: Cumulative physical trade balance $\left(\mathrm{PTB}_{1950-2010}\right)$ per area in [t/ha]. Greener colors indicate net imports per area, redder colors net exports per area. Data from Schaffartzik et al. (2014).

We identified 31 countries that have avoided substantial pressures ( $>50 \mathrm{t} / \mathrm{ha}$ ) on their domestic environments through physical imports over the 60 years accounted for. While it is clear that there are other factors shaping trade patterns, this indicator relates patterns of trade to environmental pressures. Western Europe, the United States, Japan, and South Korea, all of which have been highly industrialized for a long time, show the highest rates of PTB $_{1950-2010}$ area and interestingly also exerted the highest pressures on their domestic environments (see Figure 2). Both factors indicate that these countries have generated an ecological debt - to their own environments as well as to foreign environments - through their excessive resource use.

Among the net exporters, the countries with the highest pressure per area are important providers of fossil fuels. While most of these countries have profited economically from trade, the exploitation of nonrenewable materials exerts comparably higher pressure on the environment than processing at later stages of manufacturing, which often takes place in the countries that show up as net importers in Figure 2. In addition to the environmental impacts, the dependence on world market prices casts doubts on the long-term viability of these development paths. There is an extensive literature about negative impacts - such as the "Dutch disease", the dependency on world-market fluctuations, and scant spill-overs from mining and large-scale agriculture to the local economy - which are widely discussed in the literature on the resource curse and 
unequal exchange (Bebbington et al. 2008; Bebbington and Williams 2008; Bunker and Ciccantell 2005; Dunning 2005; Eisenmenger and Giljum 2007).

The rate between cumulative extraction and the physical trade balance in Table 3 shows the trade dependency of 11 world regions as the result of distinct trade patterns related to different material categories. The countries/regions show different grades of trade dependency across all material categories, either because there are no resources in the domestic environment, or because they have specialized in the production of exports. Countries of the Middle East and North Africa, for example, are global suppliers of fossil energy carriers; yet depend largely on food and metal imports. This exchange of fuels for food on global markets makes this region vulnerable to international food price shocks, as the global food crises of 2008 impressively showed (Harrigan 2014).

\begin{tabular}{|c|c|c|c|c|}
\hline & $\begin{array}{c}\text { PTB }_{1950-} \\
{ }_{2010} / \mathrm{DE}_{1950-} \\
2010 \text { total }\end{array}$ & $\begin{array}{c}\text { PTB }_{1950-} \\
{ }_{2010} / \mathrm{DE}_{1950-} \\
2010 \text { biomass }\end{array}$ & $\begin{array}{c}\text { PTB }_{1950-} \\
{ }_{2010} / \mathrm{DE}_{1950-} \\
2010 \text { fossil } \\
\text { fuels }\end{array}$ & $\begin{array}{c}\text { PTB }_{1950-} \\
{ }_{2010} / \mathrm{DE}_{1950-} \\
{ }_{2010} \text { metals }\end{array}$ \\
\hline Western Europe & $15 \%$ & $4 \%$ & $47 \%$ & $60 \%$ \\
\hline Eastern Asia & $9 \%$ & $6 \%$ & $35 \%$ & $52 \%$ \\
\hline Eastern \& South-Eastern Europe & $4 \%$ & $-1 \%$ & $51 \%$ & $-34 \%$ \\
\hline North America & $2 \%$ & $-7 \%$ & $13 \%$ & $5 \%$ \\
\hline Southern Asia & $-1 \%$ & $0 \%$ & $-8 \%$ & $-27 \%$ \\
\hline South-Eastern Asia & $-4 \%$ & $-3 \%$ & $-22 \%$ & $4 \%$ \\
\hline Sub-Saharan Africa & $-7 \%$ & $0 \%$ & $-47 \%$ & $-8 \%$ \\
\hline Latin America \& the Caribbean & $-7 \%$ & $-2 \%$ & $-29 \%$ & $-17 \%$ \\
\hline Central Asia and Russian Federation & $-8 \%$ & $0 \%$ & $-20 \%$ & $-5 \%$ \\
\hline Oceania and Australia & $-24 \%$ & $-8 \%$ & $-38 \%$ & $-46 \%$ \\
\hline Northern Africa and Western Asia & $-28 \%$ & $11 \%$ & $-70 \%$ & $100 \%$ \\
\hline
\end{tabular}

Table 1: Relation between $\mathrm{PTB}_{1950-2010}$ and $\mathrm{DE}_{1950-2010}$ for 11 world regions from 1950 to 2010 in per cent (e.g. PTB $_{1950-2010}$ biomass in relation to $\mathrm{DE}_{1950-2010}$ biomass). Positive values indicate net imports and negative values net exports. The higher the value, the more resources were traded in comparison to $\mathrm{DE}_{1950-2010}$. The world regions are arranged as series from relatively high net imports to high net exports.

The cumulative physical trade balances demonstrate the asymmetry of imports and exports, and Table 3 provides an overview of the relation between $\mathrm{PTB}_{1950-2010}$ and $\mathrm{DE}_{1950-2010}$, i.e. the relation between the materials extracted from a country's domestic environment and the physical trade balances. Thus, it not only shows the asymmetry of imports and exports, but also sets them in relation to material extraction. Countries in Western Europe show the highest import dependency, with 15\% compared to $\mathrm{DE}_{1950-2010}$, followed by Eastern Asia with 9\%. The highest rates are for metal ores and derived products (with more than half of the $\mathrm{DE}_{1950-2010}$ being imported), followed by slightly lower values for fossil energy carriers, and relatively lower values for biomass. Southern Asia and Sub-Saharan Africa, both regions suffering from low material standards, exported substantial shares of their fossil energy carriers and metal ores. The same pattern applies to Oceania, Latin America and the Caribbean, Central Asia, and the Russian Federation (except for biomass), with Oceania as the region with the highest rate for metal ores. Data for Northern Africa and Western Asia show that this region used fossil fuels exports revenues to import biomass and metal ores. Half of the metal ores used in this region were imported from other world regions.

Fossil energy has the most dispersed trade pattern, but biomass is also in short supply in some world regions. These regions rely on imports from other world regions to be able to feed their current populations 
and to cover additional demands, such as fodder for livestock and non-food demands such as biofuels or fibers. Metal ores and derived products, extracted from point resources, are extensively used in the industrialized regions to build up and maintain infrastructure, buildings, and machinery, but also provide key materials for a wide range of technologies (Graedel et al. 2013; Graedel and Cao 2010). Metal ores are mostly used for infrastructure and equipment, which means that they often remain in societal use for decades, or at least for longer than one year. After being discarded, they can potentially be recycled to a large degree (Haas et al. 2015; Reck and Graedel 2012; Wang et al. 2007; Wiedenhofer et al. 2015). Thus, Western Europe and Eastern Asia now own large stocks of metals as part of their infrastructure, which can be used as sources via "urban mining" in the future (Graedel 2011). However, these metal ores and products were imported from other world regions, where the extraction has often been associated with environmental and social damage (Bebbington et al. 2008; Özkaynak et al. 2012; Urkidi and Walter 2011).

\section{Conclusions: the ecological debt and the fair share concept}

There are different approaches to discussing equity in relation to resource use. Regarding climate change, the Brazilian delegation participating in the UNFCCC negotiations suggested the inclusion of historical responsibility in principles for sharing the mitigation challenge (Raupach et al. 2014). However, these discussions have not yet been reflected fully in the scientific literature on global resource use. Predictable shortages of resources and overuse of sink capacities will make distributional questions more important, and the quantification of the "fair share" of individual countries in global resource, including a historical perspective, may gain importance.

We here provide an empirical basis for discussing the ecological debt generated by individual countries through excessive consumption of physical resources, both (a) extracted from their domestic environment and (b) imported from other world regions. The environmental pressures exerted through resource extraction between 1950 and 2010 varied by orders of magnitude between individual countries and world regions. The Western European countries, oil exporters of the Middle East, and some individual providers of resources on the world markets (e.g. Chile, Indonesia, and Nigeria) had the highest extraction rates per area, while most Sub-Saharan African countries had the lowest rates. Latin American countries also exerted comparably low pressures on their domestic environments over the whole period, which is mainly a result of low resource extraction until 1990, since when rates of physical resource use in Latin America have increased. Ultimately, our data quantifies the amount of shifted environmental pressures through international trade over the course of 60 years.

Accounting for cumulative material use thus broadens the scientific analysis by including the historical perspective, while the distinction between domestic extraction and trade embraces two different aspects of cumulative material use. Material use was highly uneven between individual countries. There were net importers with high domestic material consumption who avoided environmental pressure on their domestic environment but shifted the burden mainly to net exporters. Most of the highly industrialized countries like Western Europe and the US have succeeded in this externalization of environmental pressures, which can be viewed as constituting an ecological debt towards other nations.

The analysis presented here includes the historical dimension of resource extraction and use; hence, it considers differences in speed of economic development and thus allows for a comparison of early and newly industrialized nations. The overconsumption of physical resources in some parts of the world has implications for the inter- and intra-generational equity of resource use. Such considerations should be central to contraction and convergence regulations of future global resource use.

\section{References}

Alter, H. 1997. Industrial recycling and the Basel Convention. Resources, Conservation and Recycling 19 (1): 29-53.

Ayres, R.U. 1997. Metals recycling: economic and environmental implications. Resources, Conservation and Recycling 21:145-173. 
Azar, C. and J. Holmberg. 1995. Defining the generational environmental debt. Ecological Economics 14: 719.

Bebbington, A., L. Hinojosa, D.H. Bebbington, M.L. Burneo, and X. Warnaars. 2008. Contention and ambiguity: mining and the possibilities of development. Development and Change 39: 887-914.

Bebbington, A. and M. Williams. 2008. Water and mining conflicts in Peru. Mountain Research and Development 28: 190-195.

Borras Jr., S.M. and J.C. Franco. 2012. Global land grabbing and trajectories of agrarian change: a preliminary analysis. Journal of Agrarian Change 12: 34-59.

Brundtland, G., M. Khalid, S. Agnelli, S. Al-Athel, B. Chidzero, L. Fadika, V. Hauff, I. Lang, M. Shijun, M.M. de Botero. 1987. Our common future. London: Penguin (Brundtland report).

Bunker, S.G. and P.S. Ciccantell. 2005. Globalization and the race for resources: themes in global social change. Baltimore: Johns Hopkins University Press.

Burchardt, H.-J. and K. Dietz. 2014. (Neo-)extractivism - a new challenge for development theory from Latin America. Third World Quarterly 35: 468-486.

Canadell, J.G., C.L. Quéré, M.R. Raupach, C.B. Field, E.T. Buitenhuis, P. Ciais, T.J. Conway, N.P. Gillett, R.A. Houghton and G. Marland. 2007. Contributions to accelerating atmospheric $\mathrm{CO}^{2}$ growth from economic activity, carbon intensity, and efficiency of natural sinks. Proceedings of the National Academy of Sciences 104: 18866-18870.

Debt Treaty. 1992. Non-Governmental Organization (NGO) alternative treaties at the 1992 Global Forum: alternative economic issues. Rio de Janeiro, Brazil.

Demaria, F. 2010. Shipbreaking at Alang-Sosiya (India): an ecological distribution conflict. Ecological Economics 70: 250-260.

Dietz, T., E.A. Rosa and R. York. 2007. Driving the human ecological footprint. Ecological Economics 5: $13-18$.

Dillon, J. 2001. The History of the ecological debt movement. Presented at the "Globalisation, ecological debt, climate change and sustainability," Republic of Benin.

Dirzo, R. and P.H. Raven. 2003. Global state of biodiversity and loss. Annual Review of Environment and Resources 28 137-167.

Dunning, T. 2005. Resource dependence, economic performance, and political stability. Journal of Conflict Reesolution 49: 451-482.

Eisenmenger, N., Giljum, S. 2007. Evidence from societal metabolism studies for ecological unequal trade. In Hornborg, A. and C.L. Crumley (eds.). The world system and the earth system: global socioenvironmental change and sustainability since the Neolithic. CA: Left Coast Press. Pp. 288-302.

EJOLT 2014. Environmental Justice Atlas. http://ejatlas.org (accessed 11/10/16).

Elzen, M.G., M. Berk, M. Schaeffer, J. Olivier and C. Hendriks. 1999. The Brazilian proposal and other options for international burden sharing: an evaluation of methodological and policy aspects using the FAIR model. RIVM Rapp. 728001011 Glob. Change NOP-NRP Rep. 410200029.

Elzen, M.G., M. Schaeffer and P.L. Lucas. 2005. Differentiating future commitments on the basis of countries' relative historical responsibility for climate change: uncertainties in the "Brazilian Proposal" in the context of a policy implementation. Climatic Change 71(3): 277-301.

EUROSTAT. 2012. Economy-wide material flow accounts compilation guide. Brussels: EUROSTAT.

Fischer-Kowalski, M., F. Krausmann, S. Giljum, S. Lutter, A. Mayer, S. Bringezu, Y. Moriguchi, H. Schütz, H. Schandl, and H. Weisz. 2011. Methodology and indicators of economy-wide Material Flow Accounting. Journal of Industrial Ecology 15: 855-876.

Fischer-Kowalski, M. and H. Weisz. 1999. Society as hybrid between material and symbolic realms. Advances in Human Ecology 8: 215-251.

Foley, J.A., R. DeFries, G.P. Asner, C. Barford, G. Bonan, S.R. Carpenter, F.S. Chapin, M.T. Coe, G.C. Daily, H.K. Gibbs, J.H. Helkowski, T. Holloway, E.A. Howard, C.J. Kucharik, C. Monfreda, J.A. 
Patz, I.C. Prentice, N. Ramankutty, P.K. Snyder. 2005. Global consequences of land use. Science 309: 570-574.

Goeminne, G. and E. Paredis. 2010. The concept of ecological debt: some steps towards an enriched sustainability paradigm. Environment, Development and Sustainability 12: 691-712.

Goeminne, G., W. Vanhove, F. Maes and J. Lambrecht. 2009. The concept of ecological debt: its meaning and applicability in international policy. Ghent: Academia Press.

Graedel, T.E. 2011. The prospects for urban mining. Bridge 41(1): 43-50.

Graedel, T.E. 2011. On the future availability of the energy metals. Annual Review of Materials Research 41: 323-335.

Graedel, T.E. and J. Cao. 2010. Metal spectra as indicators of development. Proceedings of the National Academy of Sciences 107 (49): 20905-20910.

Graedel, T.E., E.M. Harper, N.T. Nassar and B.K. Reck.2013. On the materials basis of modern society. Proceedings of the National Academy of Sciences 12 (20) 6295-6300.

GRAIN, Martinez-Alier, J., Temper, L., Munguti, S., Matiku, P., Ferreira, H., Soares, W., Firpo, M., Raharinirina, V., Haas, W., Singh, S.J., Mayer, A. 2014. The many faces of land grabbing: cases from Africa and Latin America. Barcelona: EJOLT.

Gudynas, E. 2010. The new extractivism of the 21st century: ten urgent theses about extractivism in relation to current South American progressivism. Americas Policy Program www.americaspolicy.org Academia

Haas W., F. Krausmann, D. Wiedenhofer and M. Heinz. 2015. How circular is the global economy? An assessment of material flows, waste production, and recycling in the European Union and the world in 2005. Journal of Industrial Ecology 19(5): 765-777.

Haberl, H., V. Gaube, R. Díaz-Delgado, K. Krauze, A. Neuner, J. Peterseil, C. Plutzar, S.J. Singh and A. Vadineanu. 2009. Towards an integrated model of socioeconomic biodiversity drivers, pressures and impacts. A feasibility study based on three European long-term socio-ecological research platforms. Ecological Economics 68: 1797-1812.

Harrigan, J. 2014. The political economy of Arab food sovereignty. Basingstoke: Palgrave.

Kastner, T., K.-H. Erb and H. Haberl 2014. Rapid growth in agricultural trade: effects on global area efficiency and the role of management. Environmental Research Letters 9: 034015.

Kastner, T., M.J.I. Rivas, W. Koch and S. Nonhebel. S. 2012. Global changes in diets and the consequences for land requirements for food. Proceedings of the National Academy of Sciences 109(18):18: 68686872.

Krausmann, F., M. Fischer-Kowalski, H. Schandl and N. Eisenmenger. 2008. The global sociometabolic transition. Journal of Industrial Ecology 12: 637-656.

Krausmann, F., S. Gingrich, N. Eisenmenger, K.-H. Erb, H. Haberl and M. Fischer-Kowalski. 2009. Growth in global materials use, GDP and population during the 20th century. Ecological Economics 68: 26962705.

La Rovere, E.L., L.V. de Macedo and K.A. Baumert. 2002. The Brazilian proposal on relative responsibility for global warming, in: Building on the Kyoto Protocol: options for protecting the climate. Washington D.C.: World Resources Institute.

Martinez-Alier, J. 2002. The environmentalism of the poor: a study of ecological conflicts and valuation. Cheltenham: Edward Elgar. Ch.1

McLaren, D. 2003. Environmental space, equity and the ecological debt. In Agyeman, J., R. Bullard and R. Evans (eds.) Just sustainabilities: development in an unequal world. Boston: MIT Press. pp. 19-37.

Muñoz, P., S. Giljum and J. Roca. 2009. The raw material equivalents of international trade. Journal of Industrial Ecology 13: 881-897.

Muradian, R. and J. Martinez-Alier. 2001. Trade and the environment: from a "Southern" perspective. Ecological Economics 36 281-297. 
Özkaynak, B., B. Gomez, M. Arsel, D. Avc1, M.H. Carbonell, B. Chareyron, F. Demaria, R. Finamore, V.V. Krishna, M. Mahongnao, A.A. Singh, T. Slavov, T. Tkalec, L. Živčič, G. Chicaiza, M. Conde, B. Kohrs, B. Raeva, I. Yánez and M. Walter. 2012. Mining conflicts around the world: common grounds from an environmental justice perspective. EJOLT report No. 7.

Paredis, E., G. Goeminne, W. Vanhove, F. Maes and J. Lambrecht. 2008. The concept of ecological debt: its meaning and applicability in international policy. Ghent: Academia Press.

Pauliuk, S., T. Wang and D.B. Müller, 2013. Steel all over the world: estimating in-use stocks of iron for 200 countries. Resources, Conservation and Recycling 71: 22-30.

Raupach, M.R., S.J. Davis, G.P. Peters, R.M. Andrew, J.G. Canadell, P. Ciais, P. Friedlingstein, F. Jotzo, D.P. van Vuuren and C. Le Quéré. 2014. Sharing a quota on cumulative carbon emissions. Nature Climate Change 4: 873-879.

Reck, B.K. and T.E. Graedel. 2012. Challenges in metal recycling. Science 337, 690-695.

Robleto, M.L. and W. Marcelo. 1992. Deuda ecológica. Santiago de Chile: Instituto de Ecologia Politica.

Rockström, J., W. Steffen, K. Noone, A. Persson, F. Stuart Chapin III, E.F. Lambin, T.M. Lenton, M. Scheffer, C. Folke, H.J. Schellnhuber, B. Nykvist, C.A. de Wit, T. Hughes, S. van der Leeuw, H. Rodhe, S. Sörlin, P.K. Snyder, P.K. R. Costanza, U. Svedin, M. Falkenmark, L. Karlberg, R.W. Corell, V.J. Fabry, J. Hansen, B. Walker, D. Liverman, K. Richardson, P. Crutzen, and J.A. Foley. 2009. A safe operating space for humanity. Nature 461: 472-475.

Sassen, S. 2013. Land grabs today: feeding the disassembling of national territory. Globalizations 10: $25-46$.

Schaffartzik, A., H. Haberl, T. Kastner, D. Wiedenhofer, N. Eisenmenger and K.-H. Erb. 2015. Trading land: a review of approaches to accounting for upstream land requirements of traded products. Journal of Industrial Ecology 19(5): 703-714.

Schaffartzik, A. and A. Mayer. 2015. Der Teufelskreis nachhaltigkeit: eine sozialmetabolische perspektive. In Simon, K.-H. and F. Tretter. (eds.). Systemtheorien und humanökologie: positionsbestimmungen in theorie und praxis. Oekom Verlag. Pp. 301-315.

Schaffartzik, A., A. Mayer, N. Eisenmenger and F. Krausmann. 2016. Global patterns of metal extractivism 1950-2010: providing the bones for the industrial society's skeleton. Ecological Economics 122: 101110. Researchgate

Schaffartzik, A., A. Mayer, S. Gingrich, N. Eisenmenger, C. Loy and F. Krausmann. 2014. The global metabolic transition: regional patterns and trends of global material flows, 1950-2010. Global Environmental Change 26: 87-97. draft

Seppaelae, J., I. Maeenpaeae, S. Koskela, T. Mattila, A. Nissinen, J.-M. Katajajuuri, T. Haermae, M.-R Korhonen, M. Saarinen and Y. Virtanen. 2009. Assessment of the environmental impacts of material flows caused by the Finnish economy with the ENVIMAT model; Suomen kansantalouden materiaalivirtojen ympaeristoevaikutusten arviointi ENVIMAT-mallilla. Summary

Smith, K.R. and M. Ezzati. 2005. How environmental health risks change with development: the epidemiologic and environmental risk transitions revisited. Annual Review of Environment and Resources 30: 291-333.

Srinivasan, U.T., S.P. Carey, E. Hallstein, P.A.T. Higgins, A.C. Kerr, L.E. Koteen, A.B. Smith, R. Watson, J. Harte and R.B. Norgaard. 2008. The debt of nations and the distribution of ecological impacts from human activities. Proceedings of the National Academy of Sciences 105: 1768-1773.

Steinberger, J.K., F. Krausmann and N. Eisenmenger. 2010. Global patterns of materials use: a socioeconomic and geophysical analysis. Ecological Economics 69: 1148-1158. Researchgate

Temper, L. and J. Martinez-Alier. 2012. Mapping resistance and resilience to the global landgrab: definitions, financial activism and alliances. Presented at the Global Land Grabbing II, Cornell University, NY.

Trudinger, C. and I. Enting. 2005. Comparison of formalisms for attributing responsibility for climate change: non-linearities in the Brazilian Proposal approach. Climatic Change 68: 67-99. 
Turner, G.M. 2008. A comparison of the Limits to Growth with 30 years of reality. Global Environmental Change 18: 397-411.

UNEP. 2011. Decoupling natural resource use and environmental impacts from economic growth. A report of the Working Group on Decoupling to the International Resource Panel. Fischer-Kowalski, M., M. Swilling, E.U. von Weizsäcker, Y. Ren, Y. Moriguchi, W. Crane, F. Krausmann, N. Eisenmenger, S. Giljum, P. Hennicke, P. Romero Lankao and A. Siriban Manalang. Geneva: United Nations Environment Programme.

Urkidi, L. and M. Walter. 2011. Dimensions of environmental justice in anti-gold mining movements in Latin America. Geoforum 42: 683-695.

Victor, P. 2010. Questioning economic growth. Nature 468: 370-371.

Vitousek, P.M., J.D. Aber, R.W. Howarth, G.E. Likens, P.A. Matson, D.W. Schindler, W.H. Schlesinger and D.G. Tilman, D.G. 1997. Technical report: human alteration of the global nitrogen cycle: sources and consequences. Ecological Applications 7: 737-750.

Wang, T., D.B. Müller and T.E. Graedel. 2007. Forging the anthropogenic iron cycle. Environmental Science and Technology 41: 5120-5129.

Warlenius, R., G. Pierce and V. Ramasar. 2015. Reversing the arrow of arrears: the concept of "ecological debt" and its value for environmental justice. Global Environmental Change 30: 21-30.

Weisz, H., F. Krausmann, C. Amann, N. Eisenmenger, K.-H. Erb, K. Hubacek, and M. Fischer-Kowalski. 2006. The physical economy of the European Union: cross-country comparison and determinants of material consumption. Ecological Economics 58: 676-698. Researchgate

Wiedenhofer, D., J.K. Steinberger, N. Eisenmenger and W. Haas. 2015. Maintenance and expansion: modeling material stocks and flows for residential buildings and transportation networks in the EU25. Journal of Industrial Ecology 19(4): 538-551.

Wiedmann, T.O., H. Schandl, M. Lenzen, D. Moran, S. Suh, J. West, and K. Kanemoto. 2015. The material footprint of nations. Proceedings of the National Academy of Sciences 112: 6271-6276.

Wilkinson, P., K.R. Smith, M. Joffe and A. Haines. 2007. A global perspective on energy: health effects and injustices. The Lancet 370: 965-978. 